\title{
MENINGKATKAN HASIL BELAJAR SISWA PADA PELAJARAN BAHASA INGGRIS DI KELAS VII-1 MELALUI PENDEKATAN PEMBELAJARAN CARA BELAJAR SISWA AKTIF DI SMP NEGERI 2 PANCUR BATU TAHUN PELAJARAN 2019/2020
}

\author{
Ade Irma Suryani \\ Guru SMP Negeri 2 Pancur Batu \\ ade73irma@gmail.com
}

\begin{abstract}
Abstrak
Tujuan penelitian ini adalah untuk: Meningkatkan hasil belajar siswa pada pelajaran Bahasa Inggris di kelas VII-1 melalui pendekatan pembelajaran cara belajar siswa aktif di SMP Negeri 2 Pancur Batu Tahun Pelajaran 2019/2020. Metode penelitian yang digunakan dalam penelitian adalah Metode Penelitian Tindakan Kelas dengan menggunakan 2 siklus. Subjek penelitian ini adalah siswa kelas VII-1 SMP Negeri 2 Pancur Batu sebanyak 35 orang, dengan rincian 18 orang siswa perempuan dan 17 orang siswa laki-laki. Instrumen pengumpulan data yang digunakan untuk memperoleh data dalam penelitian ini adalah menggunakan test, angket dan observasi. Rentang nilai untuk tes adalah 1-100. Teknik analisa data yang digunakan adalah menggunakan perhitungan jumlah nilai yang diperoleh siswa dibagi jumlah nilai total dikalikan dengan seratus kemudian perhitungan data menggunakan pengelompokan nilai rata-rata siswa, persentase siswa yang tuntas dan persentase jumlah siswa yang belum tuntas. Hasil Penelitian ini menunjukkan terdapat peningkatan hasil belajar dengan menerapkan pendekatan pembelajaran cara belajar siswa aktif dengan hasil sebagai berikut: (1) terdapat peningkatan rata-rata hasil belajar siswa, dimana pada tes awal rata-rata hasil belajar siswa adalah 42,0, pada siklus I meningkatkan menjadi 66,86 kemudian pada siklus II meningkat lagi menjadi 77,14, terdapat peningkatan jumlah siswa yang tuntas, dimana pada tes awal jumlah siswa yang tuntas hanya 0\%, meningkat menjadi 68,57\% pada siklus I kemudian meningkat lagi menjadi 85,71\% pada siklus II, terdapat penurunan jumlah siswa yang tidak tuntas, dimana pada tes awal jumlah siswa yang tidak tuntas mencapai 100\%, pada siklus I menurun menjadi 31,43\% kemudian pada siklus II menurun lagi menjadi 14,29\% dengan kata lain hanya 5 siswa saja yang memperoleh nilai 60 dan selebihnya (30) siswa memperoleh nilai di atas 70.
\end{abstract}

Kata kunci : $\quad$ hasil belajar, pendekatan pembelajaran cara belajar siswa aktif.

\begin{abstract}
The aims of this study are: (1) to improve of student achievement on English at class VII-1 through the Student Active Learning Aproach. (2) to improve learnimg activity of students. And (3) to improve students understanding and learning on Student Active Learning Aproach. The method of this study is classroom action research by using two cycles. The subject of this study is the students of VII-1 grade SMP Negeri 2 Pancur Batu. There are 35 students. They are 17 boys and 18 girls The techniques to collecting data are test, questioner and observation. The range score for test is 1-100. The technique of analysing data is to to count the average of percentage of the students who pass the standard minimal score and yet. The resullt of the study are: (1) There are the increasing average of students achivement, where pre-test is 42,0 at first cycle is increasing to 66,86 and the second cycle is increasing to 77,14 There are the increasing of the amount of students who pass the test, at the pretest the students who pass the test is $0 \%$, and the first cycle it tobe 68,57\% and the second cycle is to be $85,71 \%$. There are the decreasing of the students who fail the test. At pre-test there $100 \%$ students are fail and at first cycle is decreasing to be $31,43 \%$ and at second cycle is tobe 14,29\%. On the other hand There are only 5 students who get the score under 70 and 30 students get score more than 70.
\end{abstract}

Keywords: students achievement, english, student active learning, aproach 


\section{PENDAHULUAN}

\subsection{Latar Belakang Masalah}

Suasana belajar yang menyenangkan akan membawa dampak pada motivasi belajar dan disiplin yang meningkat. Motivasi belajar yang tinggi menjadi salah satu faktor penentu keberhasilan siswa dalam mencapai hasil belajar yang terbaik.

Berdasarkan hasil pengamatan di kelas VII-1 mata pelajaran Bahasa Inggris di SMP Negeri 2 Pancur Batu, proses belajar mengajar di kelas masih dilakukan dengan menerapkan metode konvensional (ceramah). Ketika proses pembelajaran tersebut berlangsung, banyak siswa yang tidak memperhatikan gurunya. Rasa ingin tahu siswa tidak terbangun, kemandirian dalam kegiatan pembelajaran pun sedikit sekali terlihat. Ketekunan yang dimiliki belum tampak. Selain itu hanya ada beberapa siswa yang aktif di kelas, mereka mengajukan beberapa pertanyaan yang berkaitan dengan materi yang telah diajarkan, namun masih banyak siswa yang hanya menjadi pendengar dan tergolong pasif di kelas. Saat mendapatkan nilai yang tidak memuaskan seakan menjadi hal yang biasa bagi siswa. Siswa tidak termotivasi dalam melakukan kegiatan pembelajaran.

Untuk dapat menciptakan proses pembelajaran yang berpusat kepada siswa, guru harus memiliki kompetensi. Salah satu kompetensi yang harus dimiliki oleh guru adalah memahami dan menerapkan pendekatan pembelajaran. Namun pada kenyataannya guru belum mampu menerapkan pendekatan pembelajaran yang berpusat kepada siswa. Selama ini guru belum menerapkan pendekatan pembelajaran yang dapat meningkatkan hasil belajar siswa dan dapat meningkatkan minat serta keaktifan siswa dalam mengikuti pelajaran di dalam kelas. Kemudian ditemukan juga masalah: Rendahnya kualitas pembelajaran Bahasa Inggris dan. Rendahnya hasil belajar siswa untuk mata pelajaran Bahasa Inggris. Pendekatan pembelajaran yang berpusat pada siswa adalah pendekatan cara belajar siswa aktif. Pendekatan pembelajaran ini dapat meningkatkan minat siswa dan hasil belajar siswa. Oleh sebab itu dibuat penelitian yang berjudul "Meningkatkan hasil belajar siswa pada pelajaran Bahasa Inggris di kelas VII-1 melalui Pendekatan Pembelajaran Cara Belajar Siswa Aktif di SMP Negeri 2 Pancur Batu pada Tahun Pelajaran 2019/2020.

\subsection{Perumusan Masalah}

Berdasarkan identifikasi masalah di atas, maka masalah yang dapat dirumuskan sebagai berikut:

Apakah Pendekatan Pembelajaran Cara Belajar Siswa Aktif dapat meningkatkan hasil belajar siswa pada pelajaran Bahasa Inggris Kelas VII-1 SMP Negeri 2 Pancur Batu Tahun Pelajaran 2019/2020?.

\subsection{Tujuan Penelitian}

Berdasarkan rumusan masalah di atas, maka dapat ditentukan tujuan dalam penelitian ini, yakni:

Untuk meningkatkan hasil belajar siswa pada Pelajaran Bahasa Inggris kelas VII-1 di SMP Negeri 2 Pancur Batu melalui Pendekatan Pembelajaran Cara Belajar Siswa Aktif Tahun pelajaran 2019/2020.

\subsection{Manfaat Penelitian}

Manfaat penelitian ini diharapkan berguna bagi siswa dan guru. Adapun bagi siswa penelitian ini diharapkan:

1. Keaktifan siswa dalam proses pembelajaran meningkat

2. Siswa berani mengemukakan pendapat dengan baik di depan kelas

3. Hasil Belajar Bahasa Inggris semakin meningkat.

Sementara itu bagi guru diharapkan:

Dapat merubah pola mengajar guru dari Pendekatan Pembelajaran Konvensional menjadi Pendekatan Pembelajaran Cara Belajar Siswa Aktif

\section{METODE}

\subsection{Tempat Dan Waktu Penelitian}


Penelitian ini dilaksanakan pada SMP Negeri 2 Pancur Batu Jalan Jamin Ginting Km 30 Kecamatan Pancur Batu Kabupaten Deli Serdang Provinsi Sumatera Utara. Adapun waktu penelitian ini dilaksanakan selama 6 bulan, yakni mulai dari bulan Juli 2019 sampai Desember 2019.

\subsection{Subjek Penelitian}

Subjek pada penelitian ini adalah siswa kelas VII-1 semester I (ganjil) Tahun Pelajaran 2019/2020 di SMP Negeri 2 Pancur Batu dengan jumlah siswa sebanyak 35 orang, terdiri dari 18 orang siswa perempuan dan 17 orang siswa lakilaki.

\subsection{Desain Penelitian}

Desain yang digunakan dalam penelitian ini adalah Desain Penelitian Tindakan Kelas dengan menggunakan 2 siklus, yakni: 1) perencanaan, 2) pelaksanaan, 3) evaluasi dan 4) refleksi

\subsection{Prosedur Penelitian}

Prosedur perbaikan pembelajaran yang digunakan adalah prosedur penelitian tindakan kelas dengan alur:

1. Perencanaan, yang meliputi, penetapan RPP, penetapan materi ajar, penetapan pendekatan pembelajaran, penetapan evaluasi pembelajaran, penetapan waktu pelaksanaan pembelajaran. Standar Kompetensi (SK) yang diajarkan dalam RPP Penetapan Pendekatan Pembelajaran menggunakan Pendekatan Pembelajaran Cara Belajar Siswa Aktif

2. Pelaksanaan tindakan meliputi: pelaksanaan pendekatan pembelajaran dari awal sampai akhir pembelajaran yang tertuang dalam RPP dimulai dari langkah-langkah pembelajaran dalam Pendekatan Pembelajaran Cara Belajar Siswa Aktif

3. Evaluasi, meliputi pelaksanaan evaluasi dari materi pembelajaran yang diajarkan kepada siswa. Evaluasi pembelajaran berjumlah 10 soal dengan bentuk essay test. Masingmasing soal diberi skor 10 maka total skor adalah 100. Nilai diperoleh dari jumlah skor perolehan dibagi skor maksimal dikalikan dengan 100 .

4. Refleksi meliputi, analisa dari evaluasi pembelajaran yang dilakukan oleh siswa untuk menentukan tindak lanjut yang dilakukan guna pemecahan masalah pembelajaran.

\subsection{Instrumen Penelitian}

Pada Penelitian Tindakan Kelas ini, instrumen yang digunakan berupa:

a. Tes

Instrumen tes digunakan untuk menjaring hasil belajar siswa

b. Angket

Instrumen angket digunakan untuk menjaring minat siswa

c. Observasi

Keaktifan siswa dalam proses kegiatan belajar mengajar Bahasa Inggris.

Instrumen observasi digunakan untuk mengetahui aktivitas /kegiatan pembelajaran siswa selama mengikuti pembelajaran yang menerapkan pendekatan pembelajaran cara belajar siswa aktif dan untuk memastikan bahwa guru menerapkan CBSA.

\subsection{Teknik Pengumpulan Data}

Teknik pengumpulan data yang digunakan dalam penelitian ini adalah menggunakan: (1) angket, (2) tes dan (3) observasi. Angket digunakan untuk mengumpulkan data tentang minat siswa, kemudian tes digunakan untuk menjaring data siswa, kemudian tes digunakan untuk menjaring data tentang hasil belajar siswa dan observasi digunakan untuk menjaring data tentang keaktifan siswa dalam proses belajar mengajar.

\subsection{Teknik Analisa Data}

Teknik analisa data yang digunakan adalah menggunakan perhitungan jumlah nilai yang diperoleh siswa dibagi jumlah nilai total dikalikan dengan seratus kemudian perhitungan data menggunakan 
pengelompokan nilai rata-rata siswa, jumah persentase siswa yang telah tuntas dalam pembelajaran dan jumlah persentase siswa yang tidak tuntas.

\subsection{Indikator Kinerja}

Adapun indikator kinerja dalam penelitian ini adalah jika $80 \%$ siswa memperoleh nilai sama dengan 70 atau lebih dan $80 \%$ siswa aktif dalam kegiatan belajar mengajar, maka penelitian sudah jenuh sehingga tak perlu dilanjutkan ke siklus berikutnya.

\section{HASIL DAN PEMBAHASAN}

Berdasarkan data hasil belajar
siswa, penerapan CBSA dapat meningkatkan hasil belajar siswa. Hal ini dapat dilihat dari hasil belajar siswa pada siklus I dan siklus II berikut:

1. Terdapat peningkatan rata-rata hasil belajar siswa, dimana pada tes awal rata-rata hasil belajar siswa adalah 42,0, pada siklus I meningkatkan menjadi 66,86 kemudian pada siklus II meningkat lagi menjadi 77,14.

2. Terdapat peningkatan jumlah siswa yang tuntas, dimana pada tes awal jumlah siswa yang tuntas hanya $0 \%$, meningkat menjadi $68,57 \%$ pada siklus I kemudian meningkat lagi menjadi $85,71 \%$ pada siklus II

3. Terdapat penurunan jumlah siswa yang tidak tuntas, dimana pada tes awal jumlah siswa yang tidak tuntas mencapai $100 \%$, pada siklus I menurun menjadi $31,43 \%$ kemudian pada siklus II menurun lagi menjadi 14,29\% dengan kata lain hanya 5 siswa saja yang memperoleh nilai 70 ke bawah dan selebihnya (30) siswa memperoleh nilai di atas 70 . Hal tersebut di atas dapat dilihat pada diagram di bawah ini:

\section{Diagram 4.4}

Hasil Belajar, Tes Awal, Siklus I, Siklus II

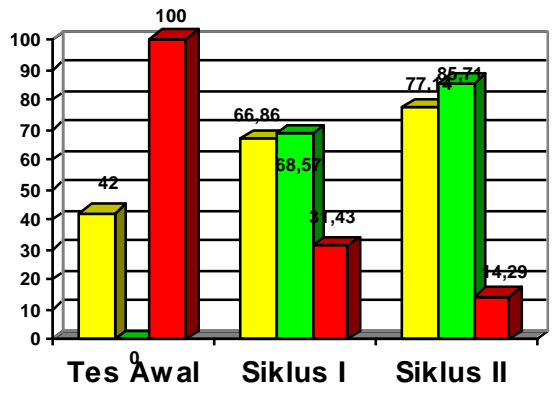

Keterangan:

$\begin{array}{ll}\text { Kuning } \square & =\text { Rata-rata } \\ \text { Hijau } \square= & \text { Tuntas } \\ \text { Merah } \square= & \text { Tidak Tuntas }\end{array}$

\section{KESIMPULAN}

Berdasarkan hasil belajar siswa di atas, maka disimpulkan bahwa: Hasil belajar siswa yang diajar menggunakan Pendekatan Pembelajaran Cara Belajar Siswa Aktif dapat meningkat, terdapat peningkatan rata-rata hasil belajar siswa, dimana pada tes awal rata-rata hasil belajar siswa adalah 42,0, pada siklus I meningkatkan menjadi 66,86 kemudian pada siklus II meningkat lagi menjadi 77,14 , terdapat peningkatan jumlah siswa yang tuntas, dimana pada tes awal jumlah siswa yang tuntas hanya $0 \%$, meningkat menjadi $68,57 \%$ pada siklus I kemudian meningkat lagi menjadi $85,71 \%$ pada siklus II, terdapat penurunan jumlah siswa yang tidak tuntas, dimana pada tes awal jumlah siswa yang tidak tuntas mencapai $100 \%$, pada siklus I menjadi $31,43 \%$ kemudian pada siklus II menurun lagi menjadi $14,29 \%$ dengan kata lain hanya 5 siswa saja yang memperoleh nilai 60 dan selebihnya (30) siswa memperoleh nilai di atas 70 .

\section{DAFTAR PUSTAKA}

Hamdani. (2011). Pendekatan Belajar Mengajar. Bandung: Pustaka Setia.

Raka, Joni. (1992). Pendekatan Pembelajaran. Jakarta: Bumi Aksara. 
Sanjaya, Wina. (2011). Pendekatan Pembelajaran Berorientasi Standar Proses Pendidikan. Jakarta: Kharisma Putra Utama.
Sugandi, A. (2004). Teori Pembelajaran. Semarang: UPT MKK Universitas Negeri Malang. 